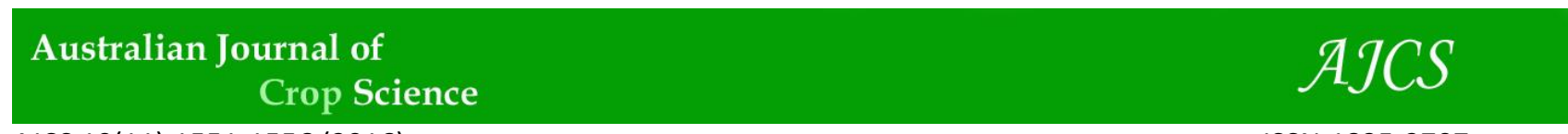

AJCS 10(11):1551-1556 (2016)

ISSN:1835-2707

doi: 10.21475/ajcs.2016.10.11.PNE122

\title{
Allelopathic activity of Eucalyptus globulus leaf aqueous extract on Hordeum vulgare growth and cytogenetic behaviour
}

\author{
Maissa M. Morsi ${ }^{1,2}$ and Hala M. Abdelmigid ${ }^{* 3,4}$ \\ ${ }^{1}$ Department of Biology, Faculty of Science, Taif University, Taif, Zip code 21944, KSA \\ ${ }^{2}$ Department of Botany, Faculty of Women for Art, Science and Education, Ain Shams University, Egypt \\ ${ }^{3}$ Department of Biotechnology, Faculty of Science, Taif University, Taif, Zip code 21944, KSA \\ ${ }^{4}$ Department of Botany, Faculty of Science, Mansoura University, Egypt
}

*Corresponding author: halaabdelmigid@yahoo.com

\begin{abstract}
Allelopathy is a major factor that influences the establishment of native species in eucalyptus forests. In this study, different concentrations of aqueous leaf extract of Eucalyptus globulus $(5 \%, 10 \%, 5 \%, 25 \%)$ were evaluated for allelopathic impacts on growth and cytogenetic behaviour of barley (Hordeum vulgare) plant. Results revealed a pronounced inhibitory effect of the aqueous extract on seed germination and seedling growth of barley plant. Cytogenetic analysis showed retardation of mitotic activity as well as occurrence of high percentage of chromosomal aberrations in Hordeum plants. Both recorded growth and cytogenetic effects were dose- dependent. At concentration 25\%, the lower value of mitotic index (MI=5.09\%) and the higher percentage of chromosome abnormalities ( $\mathrm{CA}=35.25 \%$, compared to control $(9.1 \%$ and $5.25 \%)$, respectively. The observed abnormalities were disturbance, stickiness, laggards, vagrants, bridges and micronuclei. The results confirmed the presence of water-soluble allelochemicals in Eucalyptus extract which caused potential phytotoxic, cytotoxic and genotoxic effects in barley. Hence, it is recommended that barley should not be planted close to Eucalyptus trees due to adverse effects on its growth.
\end{abstract}

Keywords: Eucalyptus globulus, Allelopathic activity, Hordeum, cytotoxicity assay, genotoxicity assay.

Abbreviations: GP_germination percentage; GR_germination speed; RGR_relative germination ratio; VI_vigor index; I_percentage of germination inhibition; MI_mitotic index; CA_chromosome abnormalities; MN_micronucleus.

\section{Introduction}

Many exotic and invasive plants are threat to ecological diversity throughout the world. Despite they are uncommon in their native range, they become very abundant in their new habitats (Dogra et al., 2011). The invasive species alter natural ecosystems and reduce plant diversity causing plant displacement by the allelopathic inhibition of germination or growth via phytotoxic chemical release (Rinez et al., 2011). Allelopathy involves the effects of one plant on another due to released chemicals, or breakdown of metabolite products.

Eucalyptus (Myrtaceae family) is native to Australia and has been widely introduced into countries throughout the world, including Saudi arabia, to produce cellulose, wood for fuel, essential oils or to sequester carbon (Zhang and $\mathrm{Fu}$, 2009). Owing to its fast growth, wide adaptability, and high productivity, many Eucalyptus species are even grown in agricultural fields with crops. In Taif region, agriculture has been the prime economic income, as historically the tribes of Taif grew wheat, barley and fruits such as lime, apricot, orange, olive, fig, peaches, pomegranate, watermelons, grapes, almonds and dates. However, on the other hand, many farmers oppose to large-scale plantations due to the possible negative allelopathic effects of Eucalyptus trees on the local flora and crops (Espinosa-Garcia et al., 2008), influencing the agriculture development in Taif area.

Germination and seedling growth are the screening criteria which are widely used to investigate the effects of allelopathy. Morphological changes, in response to allelochemicals, could be due to effects on cellular or molecular level (Dragoeva et al., 2015). Consequently, establishment of primary action of allelochemicals is of great importance. Allelochemicals may be present in the leaves, barks, roots, flowers and fruits. It has been found that the leaf extract has more powerful inhibitory allelopathic impact compared to other vegetative parts (Maharjan et al., 2007). Therefore, leaves were selected to accomplish the extract bioassays in this research.

Allelochemicals restrict plant growth through negative interactions with some physiological processes such as suppression of cell division, changes in cell wall structure and activity of some enzymes. The effects of allelochemicals action have been detected at molecular, structural, physiological, biochemical and ecological levels of plant organization (Gniazdowska and Bogatek, 2005).

Many studies have evaluated the allelopathic activity of Eucalyptus species and reported strong inhibitory effects of eucalyptus extracts on germination and growth of various plant crops e.g. cucumber, sorghum, rice, tomato, eggplant and black gram (Djanaguiraman et al., 2005; Fikreyesus et al., 2011; Dejam et al., 2014; Gliessman, 2007). Allelopathy association with Eucalyptus trees has been attributed to the presence of phenolic and volatile compounds in its foliage; the leachates of its leaves exert an inhibitory influence on understorey species through allelochemicals, such as $\alpha$ pinene, camphene and cineole (Zhang and $\mathrm{Fu}$, 
2009).Therefore, large area of ground surface beneath of eucalyptus remains bare causing limited growth of understory vegetation (El-Darier, 2002).

Cytogenetic analysis has been widely used to monitor effects of different toxic chemicals, because of several advantages such as inexpensiveness, easy handling and good correlation to other test systems (Grover and Kaur, 1999).Genotoxicity is defined as variable types of DNA damage and mutations, ranging from gene to structural or numerical chromosome changes. Mitotic activity retardation and disturbances of mitotic phases are reported as indicators of cytotoxic effect. On the other hand, the occurrence of mitotic abnormalities and induction of micronuclei in interphase cells are main criteria of genotoxic effect.

In this study, barley (Hordeum vulgare L.) was chosen as a model plant to elucidate the allelopathic potential of aqueous leaf extract of Eucalyptus globulus. Because of its ecological tolerance, barley can grow under severe conditions. It is an important agricultural crop for food, feed and also has been used virtually worldwide for intense research on mutagenesis, mutagens and mutants (Sarduie-Nasabet al, 2010). This research was designed to detect the primary action of allelochemicals in Eucalyptus trees in Taif region, through evaluation of seed germination, seedling growth as well as cytogenetic effects on barley plant. Such information should be beneficial when planning for sowing barley near or beneath of Eucalyptus trees.

\section{Results}

\section{Seed germination and seedling growth}

The allelopathic potential of eucalyptus leaf extract on growth behavior of barley is presented in Table1. Generally, significant substantial reduction in seed germination and seedling growth were influenced by eucalyptus extract in a dose reversible relationship manner. Seed germination characters expressed by GP, GR, RGR and VI of seeds exhibited substantial reduction with concentration increase. Attained percentage of germination inhibition (I) over extract concentrations varied between $1.80 \%$ and $10.82 \%$ (Table1).

The representative variables of seedling growth (radicle, shoot and seedling length) revealed substantial responses (Table1). Significant reduction in radicle length was recorded at all concentrations compared to control. Inhibition percentage in radicle lengths ranged between 31.5 and $76.8 \%$ (Fig.1). Shoot growth had different response to Eucalyptus leaf extract, revealing insignificant reduction at lower concentrations as inhibition reached $0.12 \%$ and $9.8 \%$ at $5 \%$ and $10 \%$, respectively. However, at higher concentrations (15\% and $25 \%$ ) shoot length was sharply reduced and an average reduction of length was $72.5 \%$ and $83.4 \%$, respectively (Fig.1). Accordingly, the whole seedling length also exhibited reduction in response to the aqueous extract with average inhibition ranged between $16.08 \%$ and $79.88 \%$.

\section{Mitotic index, transition of mitotic phases and cell division abnormalities}

The effects of Eucalyptus extract on cytogenetic behavior in H.vulgare were presented in Table 2. Significant $(P \leq 0.05)$ differences in MI values were observed between control and Eucalyptus leaf extract-treated groups. A concentration dependent decrease in MI value was observed and the reduction became statistically significant $(P \leq 0.05)$ at higher concentrations (15\% and 25\%).
Regarding transition of mitotic phases, the treatments changed the mitotic phase distribution in barley dividing cells. Fig. 2 shows a marked increase in percentage of prophase cells at higher doses, accompanied by reduction of other mitotic phases, especially of metaphase, and the maximal decline occurred at $25 \%$.

Results of cytogenetic analysis verified also genotoxic potential of Eucalyptus extract, represented by disturbance of mitotic process and induction of chromosome abnormalities in root-tip cells of H.vulgare. A variety of abnormalities in mitotic cells were detected at different mitotic phases. Sticky chromosomes and disturbance were the most prominent abnormalities recorded in prophase cell (Figs.3 a-c). Metaphase cells exhibited chromosome stickiness, spindle disturbances and vagrant chromosome as the most frequent abnormalities (Figs. 3d-f). Bridges, laggard, spindle disturbance, and stickiness were scored at ana-telophase cells. (Figs.3g-i). It is worthy to mention that the most common detected abnormalities in all phases were disturbance and sticky chromosomes. In general, the percentage of abnormal phases, increased at higher concentrations (35.84\% at 25\%). The MN assay revealed a substantial significant increase of micronuclei induction in interphase cells at all tested concentrations, compared to the negative control $(p \leq 0.05)$ (Table 2; Figs $3 \mathrm{j}-\mathrm{k}$ ).

\section{Discussion}

Allelopathy has been suggested as a strategy used by many invasive plants, to become dominant in their invaded plant communities (Ridenour and Callaway, 2001). Aqueous extract laboratory bioassays have been proved as simple, rapid, inexpensive and straightforward to investigate this strategy. They can also be used preliminarily to evaluate allelopathy of a suspected donor species.

Seed germination and seedling growth has been widely accepted as main variables to monitor growth responses (Anjum and Bajwa, 2005). In this context, phytotoxicity effect of E. globulus leaves was monitored in one of the most economically important crops (H.vulgare) by testing their aqueous extracts. Seed germination is considered as the most critical stage of plant development and, thus, the use of germination indices enables the testing of allelochemical effects on the physiological germination process. GP, GR, and RGR are the most common indicators of allelopathic effects which have been evaluated during the germination process. Results of the present study revealed phytotoxic effects of Eucalyptus leaf extract on the germination of the tested species. Delay in seed germination of any species have important biological implications, accordingly, the establishment of seedlings in natural conditions (Chaves et al., 2001) and their chances of competing for resources with neighboring species, will be influenced (Xingxinag et al., 2009).

Previous investigations reported that aqueous extract of some plant species contain phenolics or other toxic substances. They inhibit the germination process by their interference with gibberellins and indole acetic acid, which regulates enzymatic activity during seed germination and embryo growth (Zhang and $\mathrm{Fu}, 2009$ ). Several phenolic compounds such as caffeic, coumaric, gallic, hydroxybenzoic, syringic and vanillic acids have been identified as allelochemicals in leaf extracts of Eucalyptus (Talukdar, 2013). Allelochemicals inhibit germination and seedling growth probably by affecting cell division and elongation processes that are very important at this stage or by interfering with enzymes involved in the mobilization of 
Table 1. Seed germination and seedling growth of Hordeum vulgare under different treatments of Eucalyptus aqueous extract. The values refer to means \pm S.E. $(n=3)$. For a given measurement, means followed by the same letter within a row are not significantly different at $\mathrm{P} \leq 0.05$ level by one-way ANOVA.

\begin{tabular}{|c|c|c|c|c|c|c|c|c|}
\hline \multirow{2}{*}{$\begin{array}{l}\text { Extract } \\
\text { conc. } \%\end{array}$} & \multicolumn{4}{|c|}{ Seed germination } & \multicolumn{4}{|c|}{ Seedling growth } \\
\hline & GP & GR & RGR & I & $\begin{array}{l}\text { Radical length } \\
(\mathrm{cm})\end{array}$ & $\begin{array}{l}\text { Shoot length } \\
(\mathrm{cm})\end{array}$ & $\begin{array}{l}\text { Seedling length } \\
(\mathrm{cm})\end{array}$ & $\begin{array}{l}\text { VI } \\
\text { (VI unit) }\end{array}$ \\
\hline 0 & $99.8 \pm 0.15^{\mathrm{d}}$ & $12.4 \pm 0.04^{\mathrm{d}}$ & $100^{\mathrm{d}}$ & $0^{\mathrm{a}}$ & $9.42 \pm 0.06^{\mathrm{e}}$ & $8.54 \pm 0.054^{\mathrm{d}}$ & $17.9 \pm 0.02^{\mathrm{e}}$ & $1755.8 \pm 33.2^{\mathrm{e}}$ \\
\hline 5 & $98 \pm 0.58^{c}$ & $12.2 \pm 0.07^{\mathrm{d}}$ & $98 \pm 0.58^{c}$ & $1.80 \pm 0.44^{\mathrm{b}}$ & $6.45 \pm 0.03^{\mathrm{d}}$ & $8.53 \pm 0.052^{\mathrm{d}}$ & $15.02 \pm 0.02^{\mathrm{d}}$ & $1484.0 \pm 14.35^{\mathrm{d}}$ \\
\hline 10 & $97 \pm 0.58^{\mathrm{c}}$ & $12.1 \pm 0.7^{\mathrm{c}}$ & $97 \pm 0.58^{c}$ & $2.8 \pm 0.44^{\mathrm{b}}$ & $5.40 \pm 0.02^{b}$ & $7.7 \pm 0.028^{c}$ & $13.1 \pm 0.07^{\mathrm{c}}$ & $1271.4 \pm 8.1^{\mathrm{c}}$ \\
\hline 15 & $91 \pm 0.57^{b}$ & $11.4 \pm 0.07^{\mathrm{b}}$ & $91 \pm 0.58^{b}$ & $8.81 \pm 0.48^{c}$ & $4.99 \pm 0.06^{\mathrm{b}}$ & $2.35 \pm 0.10^{\mathrm{b}}$ & $7.35 \pm 0.11^{b}$ & $668.4 \pm 5.8^{\mathrm{b}}$ \\
\hline 25 & $89 \pm 0.58^{a}$ & $11.1 \pm 0.07^{\mathrm{a}}$ & $89 \pm 0.58^{\mathrm{a}}$ & $10.82 \pm 0.45^{\mathrm{d}}$ & $2.18 \pm 0.03^{\mathrm{a}}$ & $1.42 \pm 0.06^{\mathrm{a}}$ & $3.6 \pm 0.09^{\mathrm{a}}$ & $326.5 \pm 7.11^{\mathrm{a}}$ \\
\hline
\end{tabular}

GP_germination percentage; GR_Germination speed; RGR_relative germination ratio; I_ germination inhibition; VI_vigor index.

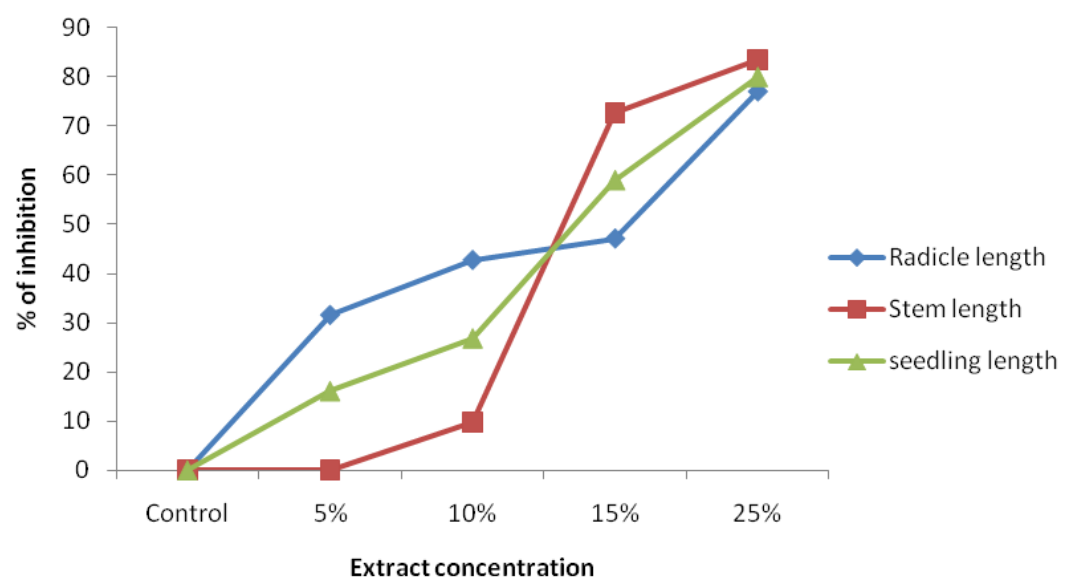

Fig 1. Allelopathic effects of Eucalyptus extract on percentage of length inhibition revealed by Radicle, Stem and whole seedling.

Table 2. Cytotoxic and genotoxic effects of Eucalyptus extract on Hordeum cells. The values refer to means \pm S.E. $(n=3)$. For a given measurement, means followed by the same letter within a row are not significantly different at $\mathrm{P} \leq 0.05$ level by one-way ANOVA.

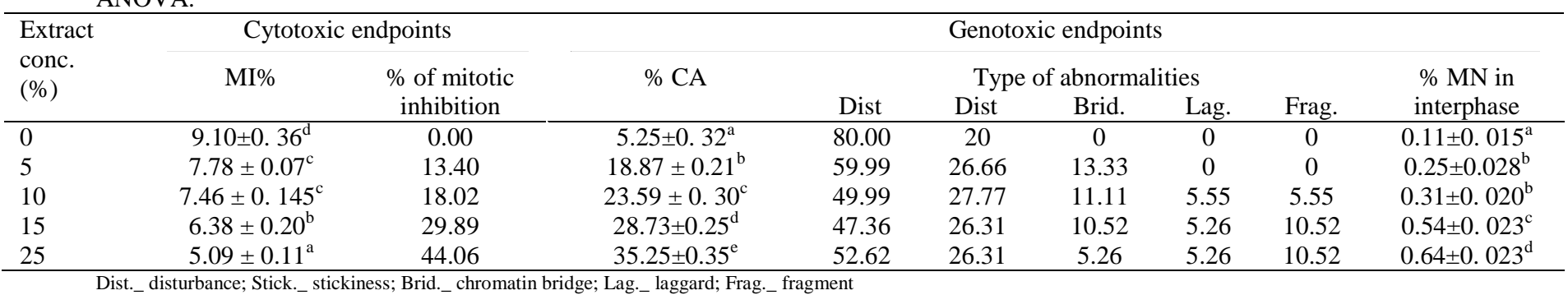

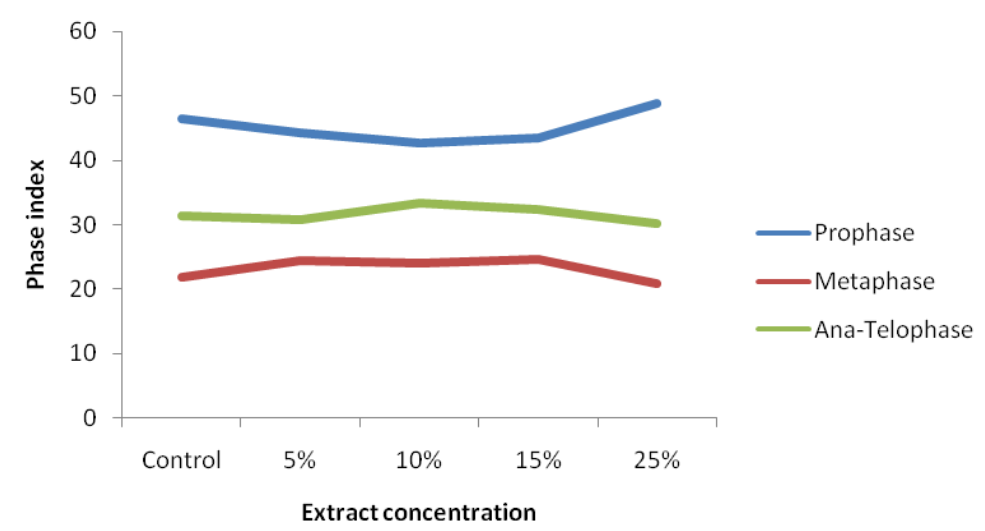

Fig 2. Allelopathic effects of Eucalyptus extract on phase index in mitotic cells of Hordeum. 


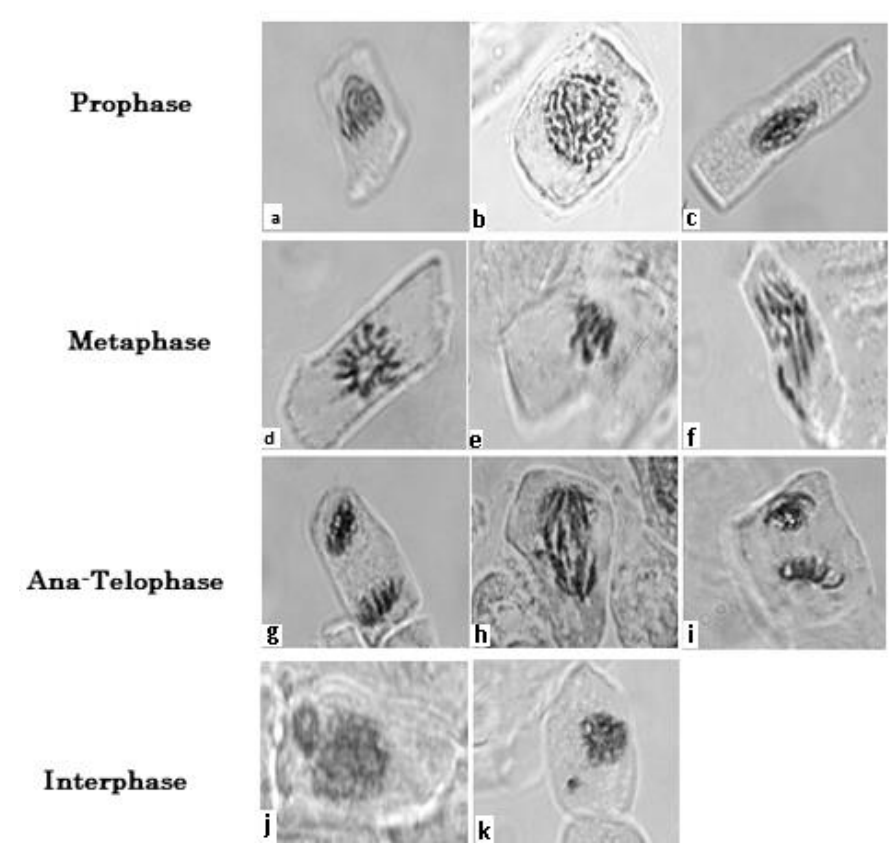

Fig 3. Different types of chromosome aberrations in Hordeum meristematic cells induced by Eucalyptus extract. (a,b): disturbed prophase, (c): prophase micronucleus, (d): disturbed metaphase, (e): sticky metaphase (f): vagrant chromosome, (g): sticky anaphase, (h): multibridges in anaphase, (i):sticky telophase, $(\mathrm{j}, \mathrm{k})$ : Micronucleus in Interphase.

nutrients necessary for germination (Batlang and Shushu, 2007). These findings were congruent with other studies on allelopathic effects of E. globulus on different crop plants (Zhang and Fu, 2009; Dejam et al, 2014).

In the growth assay, the inhibition of seedlings growth was more pronounced compared to seed germination. Both radicle and shoot lengths of target species were clearly affected by aqueous extract of E. globulus. Radicle length was strongly inhibited by aqueous extracts of leaves whereas shoot length showed less sensitivity at lower concentrations and greatly influenced at higher ones. The reduction in seedling length, most likely is owing to the inhibition of cell division and cell elongation caused by allelochemicals in the aqueous extracts (Javid and Anjum, 2006).To identify the favorable environment for the output of good quality seeds, VI (reflects the health of plants) can be estimated from more than one growth variables (germination, roots and shoots length). Treatment by leaf aqueous extract of E. globulus caused a significant reduction in VI of barley seeds, compared to control. Therefore, the attained growth indices, confirmed the phytotoxic effect of the tested Eucalyptus species on barley plant. These findings were congruent with several studies comprising different agroforestry trees (Eucalyptus camaldulensis, Prosopis julifera, Acacia nilotica), on growth of common crops such as Wheat, maize, cucumber (Lisanework and Michelson, 1993; Ghafar et al. 2000; Allolli and Narayanareddy, 2000).

In this perspective, the manifested alterations in the growth of target species could be originated by processes involved in the phase of embryonic axis growth. As allelochemicals are highly active in meristematic tissue in the growing plant (Atoum et al., 2006), they might influence the germination and early seedling growth by hindering the cell division and /or by inhibiting the elongation of cells, leading to decrease in seedling length (Fikreyesus et al, 2011; Dejam et al, 2014). As mentioned earlier, this inhibitory effect may be related to the release of phytotoxic phenolics from leaf extract, and the toxicity might be also due to synergistic effect rather than single one.

\section{Cytotoxicity assay}

Since the elongation of the roots depends on different physiological processes, including cell division, analysis of MI is one of the efficient approaches used to study allelopathic effects. In the present study, the reduction of MI values was consistent with substantial decrease in root lengths of the H.vulgare. The observed mitotic inhibitions as well as changes in the mitotic phase distribution in barley cells suggested the presence of cytotoxic allelochemicals in the tested Eucalyptus leaf extracts. MI inhibition could be interpreted as a delay in the cell proliferation kinetics or cellular death. This reduction in mitotic activity could be attributed to inhibition of DNA synthesis or a blocking in the G2 phase of the cell cycle, preventing the cell from entering mitosis (Talukdar, 2013). The depression in MI has been also suggested as a result of physiological changes induced by the extract in nuclear chromatin and chromosomal anomalies resulting in deficiency of nucleic acid and associated proteins (Asthana and Kumar, 2014). In this study, Inhibition of MI in barely dividing cells probably is owing to the mutagenic compounds in the eucalyptus extract through their action on spindle assembly or cell cycle regulators (Dragoeva et al, 2015). Similar results were reported in other crop plants (Mohamed and El-Ashry, 2012; Siddiqui, 2014). Regarding phase index, Eucalyptus extract had a pronounced effect on percentage of dividing cells in each phase. Prophase recorded the highest frequency whereas a marked decrease in percentage of metaphase cells was detected. The high frequency of prophase cells resulted from failure of dividing cells to enter into the subsequent stages, indicating a complete cessation of cell cycle due to mitotoxic effect of leaf extract. Blocking of cell division at the end of the prophase due to "freezing" of cells in the G2/M phase of the cell cycle might generate the accumulation of prophases (Siddique and Ismail, 2013). It can also be deduced that prophase build up is the result of prevention or delay of spindle fiber formation. On the other hand, the decrease in metaphase and anaphase index was noticed as the concentration increased. This may be referring to prolonged 
prophase, blocking of division at this stage or disturbance of spindle mechanism in dividing cells (Dragoeva et al, 2015).

\section{Genotoxicity assay}

Significant mitotic abnormalities were also induced by leaf extract of Eucalyptus in barley cells, suggesting genotoxic potential of the extract. These findings proved the nucleotoxic action of the extracts during cell division, which lead to chromosome aberrations (Mohamed and El-Ashry, 2012). In general, spindle failure is the main cause of numerical and structural changes in chromosomes such as cmitosis, nuclear fragmentation, lagging chromosomes, sticky chromosome and disturbed cells (Mohamed and El-Ashry, 2012). Various alkaloids such as saponins, tannins and anthraquinones, have been also reported in Eucalyptus extract and they may cause disturbance of spindle apparatus (Allolli and Narayanareddy, 2000).

Disturbed metaphases and anaphases, the most common aberrations in this study, have been considered as indicators of microtubule malformation effect of Eucalyptus extract (Dragoeva et al, 2015). Stickiness of metaphase chromosomes (the second major chromosome aberration), usually leads to the formation of anaphase and telophase bridges causing inhibition of metaphase and cytokinesis, respectively and thus retarding cell division (Asthana and Kumar, 2014). DNA depolymerization, partial dissolution of nucleoproteins, breakage and exchanges of the basic folded units of chromatids, have been indicated as the main sources of stickiness. Incidence of sticky chromosomes reflects highly toxic and irreversible effect that probably leads to cell death (Nwakanma and Okoli, 2010).

Another remarkable abnormality scored in barley mitotic cells was chromatin bridge. The bridges in the cells were probably formed due to breakage and fusion of chromatids or subchromatids. Bridges occurrence could be attributed to chromosomal stickiness, breakage and reunion and unequal translocation or inversion of chromosome segments (Singh, 2002).Vagrants and laggards (rarely noticed in this study), were possibly formed due to the interference of mutagen with spindle apparatus proteins causing inhibition of centromeric and spindle activity, and subsequent failure of chromosomes to move toward either of the poles (Asthana and Kumar, 2014). The presence of bridges, laggards and fragments indicate the clastogenic effects of eucalyptus extract on Hordeum cells.

$\mathrm{MN}$ refers to acentric fragments of damaged chromosomes which fail to find their way against the spindle during cell division. An in vitro $\mathrm{MN}$ assay can detect clastogens and aneugens as well as mitotic delay, apoptosis, chromosome breakage, chromosome loss and non-disjunction (Talukdar, 2013). Micronuclei are formed from chromatid, chromosome fragments or entire "aberrant" chromosomes, which are not included in the newly-formed daughter cells. They are formed at telophase and even extended to next interphase. The persistence of micronuclei after division might be resulted from lost fragments in anaphase or were extorted from the interphase nucleus in diminution-like manner (Siddique and Ismail, 2013). Attained results of MN assay confirmed the genotoxic effect of eucalyptus extract on barely interphase cells.

\section{Materials and Methods}

\section{Plant materials}

Fresh samples of E. globulus leaves were collected from Taif region, Saudi Arabia. The leaves were air-dried at room temperature and then ground into fine powder. Healthy uniform grains of barley (Hordeum vulgare $\mathrm{L}$ ) were obtained from the Agriculture Seed Store. Before germination test the grains were surface sterilized with $1 \%$ sodium hypochloride for $20 \mathrm{~min}$., then rinsed with the distilled water for several times.

\section{Preparation of eucalyptus extracts}

For preparation of extracts, 50, 100, 150 and 250 grams of fine powder of eucalyptus leaves were separately soaked in one liter of distilled water for about 12 hours at room temperature. The mixtures were filtered to obtain concentrations of $5 \% \mathrm{w} / \mathrm{v}, 10 \% \mathrm{w} / \mathrm{v}, 15 \%$ and $25 \% \mathrm{w} / \mathrm{v}$.

\section{Seed Germination and Seedling Growth}

Healthy and uniform size grains of barley (Hordeum vulgare) were selected and presoaked in distilled water for $2 \mathrm{~h}$ and then soaked in different concentrations of the aqueous extract for $3 \mathrm{hrs}$ and control were treated as double distilled water. Germination test was performed according to (Agraval, 2005; Siddiqui et al, 2009; Watson, 2004). Germination percentage (GP), Germination speed (GR), seed Vigor index (VI), Relative germination Ratio (RGR), and Percentage of germination Inhibition (I) were calculated. At 10 days after sowing, radicle and shoot length of recipient species seedlings were measured.

\section{Cytogenetic analysis}

Barley grains were germinated in filter paper moistened with tap water at room temperature. When the roots were $1-2 \mathrm{~cm}$ long, the grains were treated with varying concentrations $(5$, 10,15 and $25 \%$ ) of eucalyptus extract for $12 \mathrm{hrs}$. The roots were cut, fixed, hydrolyzed using $0.1 \mathrm{NHCL}$ and stained with Feulgen squash technique. Slides were photographed using oil immersion $(100 \mathrm{x})$ objectives and $15 \mathrm{x}$ eyepiece Olympus microscope camera. Five temporary slides were prepared for each treatment and control; approximately 1000 cells per slide were examined. Mitotic index, phase index and mitotic inhibition were estimated. Chromosome abnormalities were scored in Pro-metaphase and ana-telophase.

\section{Micronucleus assay (MN)}

The MN assay was conducted according to (Ma et al, 1995). In barely root tips, 1000 interphase cells per treatment from 5-7 separate slides were evaluated for micronuclei and expressed in terms MN/1000 cells.

\section{Statistical Analysis}

All experiments were conducted using the complete randomized design with 4 replications. The experimental data was subjected to the analysis of variance and means were compared using the Duncan Multiple Range Test. Different letters indicate statistical difference at $\mathrm{P} \leq 0.05$. The statistical analysis was done using the IBM/SPSS version 22 software. Figures were plotted by Excel software 2010.

\section{Conclusion}

In this study, results of the preliminary laboratory bioassays, clearly verified the allelopathic potential of Eucalyptus extract. Phytotoxic, cytotoxic and genotoxic effects are indicated, suggesting that barely crop should not be cultivated in a land surrounded by Eucalyptus trees or having Eucalyptus in agrforestry. Alternatively, seed rate must be 
increased over the normal rate to obtain the desired plant population per unit area.

\section{Acknowledgement}

The authors would like to thank the authorities of Taif University for financial support of this work. This research is a part of Project No. 1/436/4298).

\section{References}

Agraval R (2005) Seed technology. Oxford and IBH Publishing Co. 829 pp.

Allolli TB and Narayanareddy P (2000) Allelopathic effect of Eucalyptus plant extract on germination and seedling growth of cucumber. Kamataka J Agr Sci. 13 (4): 947-951.

Anjum T, Bajwa R (2005) Importance of germination indices in interpretation of allelochemical effects. Int J Agri Biol. 7(3): 417-419.

Atoum M, Al-charchafchi F, Modallal N (2006) Biological activity and anti mutagencity of water soluble phytotoxins from Artemisia herba alba ASSO. Pak J Biol Sci. 9(9): 17741778.

Asthana M, Kumar A (2014) Dose response of Viola odorata on meiotic and mitotic chromosomes of Vicia faba. Brit J Pharma Res. 4(4): 520-530.

Batlang U, Shushu DD (2007) Allelopathic activity of sunflower (Helianthus annuиs L.) on growth and nodulation of bambara groundnut (Vigna subterranean (L.) Verdc.). J Agron. 6(4): 541-547.

Chaves N, Sosa T, Escudero JC (2001) Plant growth inhibiting flavonoids in exudate of Cistus ladanifer and in associated soils. J Chem Ecol. 27 (3): 623-631.

Dejam M, Khaleghi SS, Ataollahi R (2014) Allelopathic effects of Eucalyptus globulus Labill. on seed germination and seedling growth of eggplant (Solanum melongena L.). Intl J Farm Alli Sci. 3 (1): 81-86.

Djanaguiraman M, Vaidyanathan R, Annie sheeba J, Durgadevi D, Bangarusamy U (2005) Physiological responses of Eucalyptus globulus leaf leachate on seedling physiology of rice, sorghum and blackgram. Intl J Agri Biol.7 (1):35-38.

Dogra KS, Sood SK, Sharma R (2011) Distribution, biology and ecology of Parthenium hysterophorus L. (congress grass) an invasive species in the North-Western Indian Himalaya (Himachal Pradesh). Afr J Plant Sci. 5(11):682-687.

Dragoeva AP, Koleva VP, Nanova ZD, Georgiev BP (2015) Allelopathic effect of Adonis vernalis L.: Root growth inhibition and cytogenetic alterations. J Agri Chem Environ. 4: 48-55.

Espinosa-Garcia FJ, Martinez-Hernandez E, Quiroz-Flores A (2008) Allelopathic potential of Eucalyptus spp plantations on germination and early growth of annual crops. Allelopathy J. 21 (1):25-37.

El-Darier SM (2002) Allelopathic effects of Eucalyptus rostrata on growth, nutrient uptake and metabolite accumulation of Vicia faba L. and Zea mays L. Pak J Biol Sci. 5 (1): 6-11.

Fikreyesus S, Kebebew Z, Nebiyu A, Zeleke N, Bogale S (2011) Allelopathic effects of Eucalyptus camaldulensis Dehnh. on germination and growth of tomato. Am-Eurasian $\mathbf{J}$ Agri Environ Sci. 11 (5): 600-608.

Ghafar A, Saleem B, Qureshi MJ (2000) Allelopathic effects of sunflower on germination and seedling growth of wheat. Pak J Biol Sci. 3 (8): 1301-1302.

Gliessman SR (2007) Allelopathic Effects of Crops. Technology \& Engineering, Santa Cruz. 384 p.
Gniazdowska A, Bogatek R (2005) Allelopathic interactions between plants. Multi site action of allelochemicals. Acta Physiol Plant. 27: 395-407.

Grover IS, Kaur S (1999) Genotoxicity of wastewater samples from sewage and industrial effluent detected by the Allium root anaphase aberration and micronucleus assays. Mutat Res. 426 , pp. $183-188$

Javaid A, Anjum T (2006) Control of Parthenium hysterophorus L., by aqueous extracts of allelopathic grasses. Pak J Bot. 38(1): 139-145

Lisanework N, Michelen A (1993) Allelopathy in agroforestry systems. The effects of leaf extracts of eucalyptus species on three crops. Agro-forestry Syst. 21(1): 63-74.

Ma TH, Xu Z, Xu C, McConnell H, Rabago E Arreola GA, Zhang H (1995) The improved Allium/ Vicia root tip micronucleus assay for clastogenicity of environmental pollutants. Mut Res. 334: 185-195.

Maharjan S, Shrestha BB, Jha PK (2007) Allelopathic effects of aqueous extracts of leaves of Parthenium hysterophorus L. on seed germination and seedling growth of some cultivated and wild herbaceous species. Sci World. 5(5): 33-39.

Mohamed FI, El-Ashry ZM (2012) Cytogenetic effect of allelochemicals Brassica nigra L. extracts on Pisum sativum L. World Appl Sci J. 20 (3): 344-353.

Nwakanma NMC, Okoli BE (2010) Cytological effects of the root extracts of Boerhaavia diffusa on root tips of Crinum Jagus. Eur Asia J Bio Sci. 4: 105-111.

Ridenour WM, Callaway RM (2001) The relative importance of allelopathy interference: the effects of an invasive weed on a native bunchgrass. Oecologia. 126(3):444-450.

Rinez A, Ladhari A, Omezzine F, Rinez I, Haouala R (2011) Phytotoxicity of Nicotiana glauca graham aqueous extracts a Tunisian invasive plant. $3^{\text {rd }}$ International Symposium on Weeds and Invasive Plants. October 2-7.

Sarduie-Nasab S, Sharifi-Sirchi GR, Torabi-Sirchi MH (2010) Assessment of dissimilar gamma irradiations on barley (Hordeum vulgare spp.). J Plan Breed Crop Sci. 2(4):059063.

Siddique MA, Ismail BS (2013) Allelopathic effects of Fimbristylis miliacea on the physiological activities of five Malaysian rice varieties. Aust J Crop Sci. 7(13):2062-2067

Siddiqui S (2014) Genotoxic effect of four medicinal plant extracts on Pisum sativum CV. ARIKIL. Bangl J Bot. 43(1): 107-111.

Siddiqui S, Ruchi Y, Kavita Y, Ahmad FW, Mukesh S, Sudarshana K M, Farah J (2009) Allelopathic potentialities of different concentrations of aqueous extract of some arable trees on germination and radicle growth of Cicer arietinum Var. C-235. Global J Mol Sci. 4(2): 91-95.

Singh RJ (2002) Plant Cytogenetics. CRC Press, London.

Talukdar D (2013) Allelopathic effects of Lantana camara L. on Lathyrus sativus L.: Oxidative imbalance and cytogenetic consequences. Allelopathy J. 31 (1): 71-90

Watson K (2004) The Effect of Eucalyptus and Oak Leaf Extracts on California Native Plants. College of Natural Resources, University of California, Berkeley Internet document, socrates. Berkeley. edu/ es196/projects/ 2000final/watson.pdf

Xingxinag G, Li Zongjung MG, Changsong L, Zuowen S (2009) Allelopathic effects of Hemisterpa lyrata on the germination and growth of wheat, sorghum, cucumber, rape and radish seeds. Weed Biol Manag. 9: 243 - 249.

Zhang C, Fu S (2009) Allelopathic effects of eucalyptus and the establishment of mixed stands of eucalyptus and native species. Forest Ecol Manag. 258:1391-1396. 